\title{
sciendo
}

\section{Online booking for travel and accommodation influenced by economic and digital development level: Position of the Western Balkan countries within Europe}

\author{
Berislav Žmuk \\ University of Zagreb, Faculty of Economics and Business, Department of \\ Statistics, Zagreb, Croatia \\ bzmuk@efzg.hr \\ Iris Mihajlović \\ University of Dubrovnik, Department of Economics and Business Economics, \\ Dubrovnik, Croatia \\ iris.mihajlovic@unidu.hr
}

\begin{abstract}
The expansion of the Internet has radically changed the way in which citizens travel, book and organise travel arrangements. Since innovation and new information technologies have become crucial determinants to encourage competitiveness in the tourism sector in Europe, this article investigates how selected development indicators influence the Percentage of individuals that use Internet for travel and accommodation services. Eurostat data for 34 European, European Union (EU-28) and selected EU candidates, countries for 2017 were analysed. It has been presented that (1) Gross Domestic Product per capita in Purchasing Power Standards; (2) Percentage of population aged 15 to 64, by tertiary education; as well as (3) Percentage of individuals aged 16 to 74, who have basic or above basic overall digital skills, all correlate positively and strongly with the main variable under study. The conducted regression analysis has shown that variable digital skills has the greatest impact on the main variable under the study. The K-mean clustering of countries resulted with four clusters. The Western Balkan countries can be found in a cluster which has in average the lowest values of all four variables in compare to the averages of other three clusters.
\end{abstract}

Keywords: Internet booking for travel and accommodation, k-means clustering, outliers, regression diagnostics, Western Balkan countries.

JEL classification: C10, C38.

DOI: 10.2478/crebss-2018-0016

Received: September 20, 2018

Accepted: November 23, 2018

Acknowledgments: This work has been supported by Croatian Science Foundation under the project STatistical Modelling for REspoNse to Crisis and Economic GrowTH in WeStern Balkan Countries - STRENGTHS (No.: IP 2013-9402). 


\section{Introduction}

According to Mondekar (2017), who analysed the Digital Economy in Southeast Europe, emphasizing opportunities and challenges, the digital economy is a part of the World's global trends. Internet changes introduce prosperity to mobility in general, but especially to tourism, education, financing, living and Transportation, becoming a great test for traditional business models, changing the lives of the citizens.

European Commission (2017) reported on Special Eurobarometer on "attitudes towards the impact of digitisation and automation on daily life", based on a large scale survey research of EU citizens, who were interviewed in March 2017. Three quarters of Europeans think that digitisation effects the economy positively, replacing more jobs than it creates, and two thirds of Europeans think that it influences positively on the society. More than $40 \%$ of respondents who are employed think that their jobs could partially be replaced by artificial intelligence or a robot. According to European Commission (2018a), the Digital Economy and Society Index (DESI), which is an online tool to measure the progress of EU Member States towards a digital economy and society, considers Europe's current digital policy mix. It includes five main dimensions, among which use of Internet for e-commerce (online selling, cross border selling).

Tourism sector plays a significant role for the whole Europe, as the most important World destination. Being a major economic activity in the European Union, tourism impacts widely on growth of the economies, social development and employment. It appeared to be a prevailing means against unemployment and economic weakening. Nowadays the tourism sector has a number of challenges. The European Commission works to address these with policies and actions. In European Commission (2018b) overview of EU tourism policy is presented. Besides economic competitiveness, growing demand of new products, security and safety issues of the European tourism industry, as the most challenging factor technological issues are focused, such as keeping up to date with IT developments caused by the globalisation of information and advances in technology, IT tools for booking holidays, social media providing advice on tourism services, etc.

Not only the European Union member states (EU-28), but candidate countries from the Western Balkans are pushed by the tourism sector, and especially Croatia and Montenegro. The Institute of Economics Zagreb (2018) SEE-6 Economic Outlook gives an outline of economic trends and short-term forecasts for the six countries of Southeast Europe: Bosnia and Herzegovina, Croatia, Macedonia, Montenegro, Serbia and Slovenia. It has been discussed the economic trends in the mentioned countries providing the analysis of the Global Competitiveness Index (GCl), indicator introduced in 1979 by World Economic Forum, which measures the driving factors long-term growth and prosperity. In line with the overall $\mathrm{GCl}$ index, the most competitive SEE-6 country appeared to be Slovenia, ranked as 48th in the World in 2017, whereas Bosnia and Herzegovina rank has been ranked 103rd, being the lowest as compared to the remaining five SEE countries. The other SEE-6 countries have the rank close to each other: Macedonia (68), Croatia (74), Montenegro (77), and Serbia (78). Recently, Serbia and Slovenia approaches the competitiveness gap to the most competitive economies of the World. Croatia is ranked with no specific trend, more or less stable. Bosnia and Herzegovina and Montenegro have got negative trend. Macedonia, showed a positive trend up to 2015, but slightly declined in 2016. 
The authors of this paper were curious about digitalisation and economic development impacts on booking for travel and accommodation. So, in this paper, two research hypotheses have been defined. In the first hypothesis it is stated that the highest importance on online booking for travel and accommodation should have variable digital skills. The second research hypothesis assumes that the Western Balkan (WB) countries have undeveloped online booking for travel and accommodation level in compare to the other European countries. The hypotheses have been tested for the WB countries with the available data.

The paper is organized as follows. After the brief introduction, in the second section literature review is provided. In the third section attention to used data and methods is given. Following three sections are dedicated to data analysis. Firstly, the data are described by using different descriptive statistics methods. After that the correlation and regression analysis was applied. Finally, the clustering analysis was conducted. The final section of the paper concludes it.

\section{Literature review}

The rise of the internet usage has visibly changed the way of travelling and booking accommodation and arrangements, as well as the manner the enterprises are doing business in tourism. The European Commission (2010) promoted Europe as the world's No 1 tourist destination, defining the mainstream and a new political framework for tourism in Europe, highlighting that innovation and new information technologies have become responsible features to encourage competitiveness in the European tourism sector. After the 2008 crisis, European tourism is by the strategic means strongly encouraged towards an increase.

Minghetti and Buhalis (2010) are emphasizing Digital Divide in tourism and proposes an incorporated theoretical framework to discover the main aspects, which lead to equal access and use of ICTs for both tourists and destinations. It treats all social, and motivational concerns, as well as technical aspects, resulted from various digital divide analysis with the goal to recognize how these features influence the markets' and destinations' capacity to act together effectively within a tourism background globally.

The authors studied the Eurostat online booking indicator, using variety of statistical methods, mostly with data form 2013 for EU-28 and candidate countries. So, Žmuk, Dumičić and Mihajlović (2014) perform descriptive and cluster analysis of European countries regarding online booking of individuals for travel and holiday accommodation and selection of development indicators. Firstly, positive correlation with four independent variables, GDP per capita, Public expenditure on education, Internet penetration rate and the Individuals' level of Internet skills, was recognized. Further, hierarchical clustering gathered in the same cluster Bulgaria, Romania, Turkey, the Former Yugoslav Republic (FYR) of Macedonia and Serbia. In the same time, Croatia did not join the cluster of these SEE countries, even though having an under-average percentage of individuals who are booking online, similarly to those countries, but it joined the cluster of the developing EU countries, respecting variables under study.

Dumičić, Žmuk and Čeh Časni $(2015,2016)$ analysed online booking for travel and holiday accommodation, as the main variable under study using more multivariate methods. In Dumičić, Žmuk and Čeh Časni (2015) authors conducted multiple regression modelling, when analysing the impacts on online booking for travel and holiday accommodation in 2013 for selected South-East European (SEE) countries, the European Union (EU28) countries and EU candidates, Turkey, the FYR of Macedonia and Serbia. The influence of Internet penetration rate and ICT skills on 
the percentage of individuals who booked travel and holiday accommodation online was studied. Authors applied hierarchical and non-hierarchical clustering methods, as well. The SEE countries, and Turkey, the FYR of Macedonia, Serbia, Bulgaria and Romania were gathered in the same cluster. Other more developed SEE countries joined the other EU countries.

Later on, Dumičić, Žmuk and Čeh Časni (2016) performed regression analysis based on two recognized factors resulting from the factor analysis of determinants of internet booking usage for the same selection of countries, but with more variables. Online booking as the main variable under study was regressed on these two factors. Factors were extracted using the principal component analysis, the first, Economic Factor, was comprised of Gross Domestic Product (GDP) per capita in Purchasing Power Standards (PPS), the share of GDP given for education and the Internet penetration rate. The second was Internet Skills Factor. Both recognized factors influenced online booking for travel and holiday accommodation, as the dependent variable.

Dumičić, Žmuk and Mihajlović (2016) conducted a panel analysis for 31 selected European countries, from 2003 to 2014 , with the goal to determine the individual and the common impact of the development indicators on online booking. The analysis has shown that the share of GDP for education, an individual's wealth and the Internet penetration rate have a positive influence on online booking, though the percentage of individuals with low level Internet skills has a negative influence.

Mihajlović (2014a) analysed the influence of global trends on of travel intermediaries' transformation at the of macro environment level, focusing Croatia. In Mihajlović (2014b) new challenges for intermediaries influenced by new trends in consumer behaviour and new ICT solutions were studied.

Mihajlović, Milić Beran, and Krželj Čolović (2014), analysed the role of technological innovations as a prerequisite of the communication efficiency between service providers and tourists who need to decide about travel, while Mihajlovic, and Raguz (2018) recognized the key drivers of business transformations in the travel intermediaries environment.

\section{Data and methods}

In the paper overall four carefully chosen variables will be observed. The main variable under the study is variable INTBOOK which represents percentage of all individuals that use Internet for travel and accommodations services. According to the literature review following three variables have been chosen as the most appropriate to describe changes in the variable INTBOOK: gross domestic product (GDP) per capita in purchasing power standards (PPS) given as indices where EU28=100 (GDPpc_PPS); percentage of population with tertiary education aged from 15 to 64 years (EDUC_L5-L8); percentage of individuals aged from 16 to 74 years who have basic or above basic overall digital skills (DIGSKILLS). Data for all data was collected from Eurostat database (Eurostat, 2018a-d).

The data were collected for the following 34 European countries: Belgium; Bulgaria; Czech Republic; Denmark; Germany; Estonia; Ireland; Greece; Spain; France; Croatia; Italy; Cyprus; Latvia; Lithuania; Luxembourg; Hungary; Malta; Netherlands; Austria; Poland; Portugal; Romania; Slovenia; Slovakia; Finland; Sweden; United Kingdom; Iceland; Nonway; Switzerland; Montenegro; the Former Yugoslav Republic of Macedonia; Turkey. The first 28 listed countries are current European Union member states whereas the other countries are closely related or are even European Union candidate. All collected data contained information about the 
variable values related to 2017. However, due to missing value, the DIGSKILLS variable value for Italy was estimated by taking value from 2016.

In the first step, the descriptive statistical analysis of all four observed variables will be conducted. On that way the main characteristics of variables will be revealed and possible outliers will be detected. In order to detect presence of outliers in the datasets Grubbs' test or the maximum normed residual test and standardized variable approach will be used. If there are found out to be some outliers, they will be excluded from the following analyses.

After descriptive statistics analysis, correlation and linear regression modelling will be applied. The relationship of the variable INTBOOK, the main variable under the study, with other three variables will be inspected separately by forming simple linear regression models. Multiple linear regression modelling will be applied as well but only statistically significant and valid regression models will be shown.

In order to group countries according to their characteristics, the cluster analysis will be conducted. K-means clustering approach will be applied. The contents of resulting clusters will be commented and discussed with special focus on the WB countries.

\section{Exploratory data analysis}

In order to reveal the main characteristics of the observed variables the descriptive statistical analysis was conducted and the results are given in Table 1.

Table 1 Descriptive statistics results for all four observed variables, n=34 countries, data for 2017

\begin{tabular}{|l|r|r|r|r|}
\hline \multirow{2}{*}{ Statistics } & \multicolumn{4}{|c|}{ Variables } \\
\cline { 2 - 5 } & INTBOOK & GDPPC_PPS & EDUC_L5-L8 & DIGSKILLS \\
\hline Mean & 37.94 & 99.41 & 28.48 & 57.24 \\
Median & 40.00 & 90.50 & 29.85 & 55.50 \\
Mode & 57.00 & 77.00 & Multiple & 50.00 \\
Frequency of mode & 3 & 3 & 2 & 4 \\
Sum & $1,290.00$ & $3,380.00$ & 968.40 & $1,946.00$ \\
Minimum & 10.00 & 37.00 & 15.30 & 29.00 \\
Maximum & 71.00 & 253.00 & 39.60 & 85.00 \\
Lower Quartile & 23.00 & 68.00 & 20.90 & 48.00 \\
Upper Quartile & 56.00 & 123.00 & 35.30 & 71.00 \\
Range & 61.00 & 216.00 & 24.30 & 56.00 \\
Quartile Range & 33.00 & 55.00 & 14.40 & 23.00 \\
Variance & 320.84 & 1857.76 & 56.86 & 242.06 \\
Standard deviation & 17.91 & 43.10 & 7.54 & 15.56 \\
Coefficient of var. & 47.21 & 43.36 & 26.47 & 27.18 \\
Skewness & -0.08 & 1.54 & -0.25 & 0.03 \\
Kurtosis & -1.22 & 3.76 & -1.37 & -0.70 \\
\hline
\end{tabular}

Source: authors.

According to the results from Table 1, the average percentage of individuals that use Internet for travel and accommodation services is $37.94 \%$. Median value shows that in $50 \%$ of observed countries $40 \%$ or less individuals use Internet for travel and accommodation services whereas in $50 \%$ countries there are $40 \%$ or more such individuals. The range at variable INTBOOK is 61 percentage points which suggests that there are great differences of percentage of individuals that use Internet for travel and accommodation services between the countries. Coefficient of variation, of $47.21 \%$, confirms that there is present high level of data variability. 
The variable GDPpc_PPS is given as index variable where EU28 average is set to be 100 . The median value indirectly shows that there are more than $50 \%$ of countries in the sample that have GDPpc_PPS value below that average. In addition, the range shows that the difference between the developed and the undeveloped countries is huge. The great variability of variable GDPpc_PPS is confirmed by coefficient of variation value (43.36\%). The variability levels at variables EDUC_L5-L8 and DIGSKILLS are not as high as at previous two variables but the ranges reveal that there are great differences between countries with the highest and the lowest values of the observed variables.

Table 2 Grubbs test results for $n=34$ and for $n=33$ countries

\begin{tabular}{|l|r|r|r|r|}
\hline \multirow{2}{*}{ Variable } & \multicolumn{2}{|c|}{$\mathrm{n}=34$ countries } & \multicolumn{2}{c|}{$\mathrm{n}=33$ countries } \\
\cline { 2 - 5 } & Grubbs test statistic & $\mathrm{p}$-value & Grubbs test statistic & $\mathrm{p}$-value \\
\hline INTBOOK & 1.8456 & 1.0000 & 1.5667 & 1.0000 \\
GDPpC_PPS & 3.5633 & 0.0023 & 2.6244 & 0.1865 \\
EDUC_L5-L8 & 1.7482 & 1.0000 & 1.7141 & 1.0000 \\
DIGSKILLS & 1.8148 & 1.0000 & 1.9079 & 1.0000 \\
\hline
\end{tabular}

Source: authors.

The Grubbs test was applied to detect whether an outlier is present in the dataset. The null hypothesis of the Grubbs test has a statement that in the dataset are no outliers whereas the alternative hypothesis contains statement that there is present one outlier (Žmuk, 2017). According to Table 2, when all 34 countries are observed, the conducted Grubbs test shows, at significance level of $5 \%$, that there is an outlier at variable GDPPc_PPS. The standardized variable has shown that the lowest z-score at variable GDPpc_PPS is -1.45 whereas the largest is 3.56 . Accordingly, it can be concluded that the highest value at variable GDPPC_PPS can be considered as an outlier. Consequently, Luxembourg, which has the highest value at variable GDPpc_PPS, is omitted and therefore in all further analyses 33 countries are observed.

In addition, the Grubbs test was conducted again after omitting Luxembourg. The results from Table 2 are suggesting, at significance level of $5 \%$, that there are no more outliers present in the datasets.

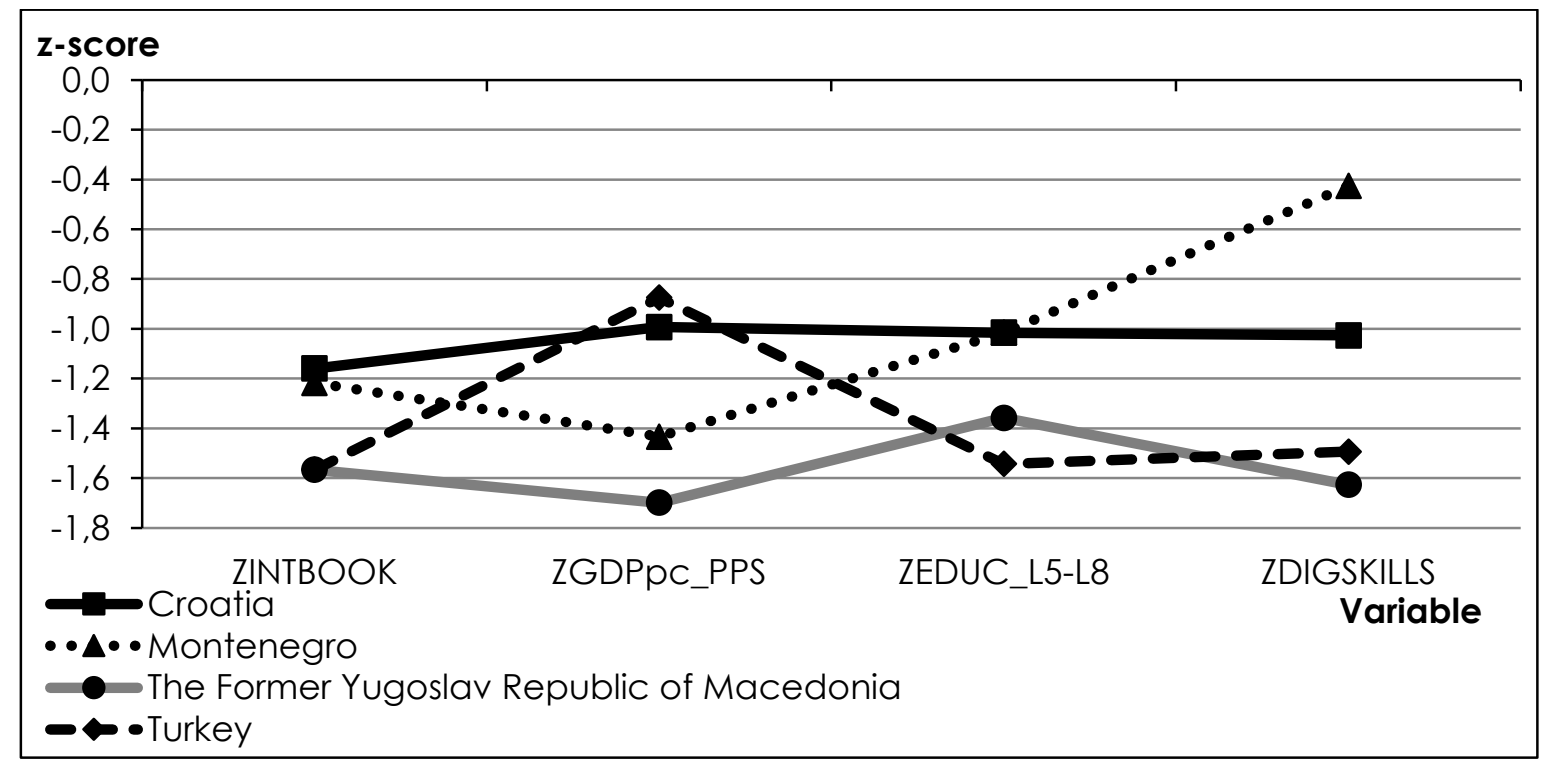

Figure 1 Profile diagrams of observed Western Balkan countries

Source: authors. 
In the dataset it can be found four WB countries: Croatia, Montenegro, the Former Yugoslav Republic of Macedonia and Turkey. Unfortunately, for other WB countries data was unavailable. In Figure 1 profile diagrams based on the standardized values of observed variables of the four WB countries are shown. The profile diagrams reveal that the observed WB countries are really below the average at all four observed variables. In addition, the Former Yugoslav Republic of Macedonia and Turkey have the lowest values of variable INTBOOK among all observed European countries.

\section{Regression modelling for explanation of online booking}

According to the conducted literature interview, there should be statistically significant correlation of the main variable under the study, INTBOOK, with each of the other three observed variables separately. In order to inspect that, the correlation matrix was calculated and presented in Table 3.

Table 3 Correlation matrix, $\mathrm{n}=33$ countries

\begin{tabular}{|l|l|l|l|l|}
\hline Variables & INTBOOK & GDPPC_PPS & EDUC_L5-L8 & DIGSKILLS \\
\hline INTBOOK & 1.0000 & $0.8100^{* * *}$ & $0.6746^{* * *}$ & $0.9096^{* * *}$ \\
GDPPC_PPS & $0.8100^{* * *}$ & 1.0000 & $0.6539^{* * *}$ & $0.7156^{* * *}$ \\
EDUC_L5-L8 & $0.6746^{* * *}$ & $0.6539^{* * *}$ & 1.0000 & $0.6512^{* * *}$ \\
DIGSKILLS & $0.9096^{* * *}$ & $0.7156^{* * *}$ & $0.6512^{* * *}$ & 1.0000 \\
\hline
\end{tabular}

Note: statistically significant at significance level of: ${ }^{*} 10 \%,{ }^{* *} 5 \%,{ }^{* * *} 1 \%$.

Source: authors.

According to results from Table 3 variable INTBOOK has statistically highly significant linear, positive and strong correlations with each of the other three variables. Therefore it makes sense to believe that simple linear regression models, where INTBOOK has role of dependent variable and the other three variables have roles of independent variables, will be statistically significant as well. The main results of the conducted simple linear regression modelling are shown in Table 4.

Table 4 Main results of the simple linear regression models, dependent variable INTBOOK, $n=33$ countries

\begin{tabular}{|c|c|c|c|}
\hline Statistics & Model 1 & Model 2 & Model 3 \\
\hline Independent variable & GDPpc_PPS & EDUC_L5-L8 & DIGSKILLS \\
\hline Intercept $\left(\hat{\beta}_{0}\right)$ & $\begin{array}{r}-1.8720 \\
(5.3531)\end{array}$ & $\begin{array}{l}-6.3157 \\
(8.7936)\end{array}$ & $\begin{array}{l}-21.8918^{* * *} \\
(4.9880)\end{array}$ \\
\hline Slope $\left(\hat{\beta}_{1}\right)$ & $\begin{array}{l}0.4096^{* * *} \\
(0.0533)\end{array}$ & $\begin{array}{l}1.5276^{* * *} \\
(0.3003)\end{array}$ & $\begin{array}{l}1.0432^{* * *} \\
(0.0856)\end{array}$ \\
\hline Standardized slope & $\begin{array}{l}0.8100^{* * *} \\
(0.1053)\end{array}$ & $\begin{array}{l}0.6746^{* * *} \\
(0.1326)\end{array}$ & $\begin{array}{l}0.9096^{* * *} \\
(0.0746)\end{array}$ \\
\hline R-squared & 0.6561 & 0.4550 & 0.8274 \\
\hline Standard error of regression & 10.2460 & 12.8973 & 7.2574 \\
\hline F-statistic & $59.1298^{* * *}$ & $25.8831^{* * *}$ & $148.6473^{* * *}$ \\
\hline Durbin-Watson statistic & 1.6395 & 1.2700 & 1.6400 \\
\hline Breusch-Godfrey serial correlation LM test stat. & 1.1457 & $5.9635^{*}$ & 1.2725 \\
\hline Jarque-Bera test statistic & $4.8224 *$ & 0.2427 & 0.9371 \\
\hline Breusch-Pagan-Godfrey heterosked. test stat. & $5.9367^{* *}$ & 0.0018 & 0.0190 \\
\hline
\end{tabular}

Note: statistically significant at significance level of: ${ }^{*} 10 \%,{ }^{* *} 5 \%,{ }^{* * *} 1 \%$.

Source: authors. 
The results from Table 4 confirmed assumption that all three simple linear regression models will be statistically significant. Furthermore, the results presented in Table 4 show that all prerequisites of simple linear regression model are fulfilled at all three observed models. At all three linear regression models it has been shown that one unit increase of independent variable will result in increase of the dependent variable as well. However, it has been shown that the highest absolute impact on dependent variable INTBOOK has variable DIGSKILLS. Namely, it has been shown that one standard deviation increase of variable DIGSKILLS would in average result in 0.9096 standard deviations increase of variable INTBOOK.

Table 5 Main results of the multiple linear regression model, dependent variable INTBOOK, the first independent variable GDPpc_PPS, the second independent variable DIGSKILLS, $n=33$ countries

\begin{tabular}{|l|c|}
\hline \multicolumn{1}{|c|}{ Statistics } & Model 4 \\
\hline Independent variables & $\begin{array}{c}\text { GDPPC_PPS (X1) } \\
\text { DIGSKILLS (X2) }\end{array}$ \\
\hline Intercept $\left(\hat{\beta}_{0}\right)$ & $-22.4249^{* * *}$ \\
& $(4.2436)$ \\
$\hat{\beta}_{1}$ & $0.1648^{* * *}$ \\
$\hat{\beta}_{2}$ & $(0.0459)$ \\
\hline Standardized $\hat{\beta}_{1}$ & $0.7757^{* * *}$ \\
& $0.1042)$ \\
\hline Standardized $\hat{\beta}_{2}$ & $0.3259^{* * *}$ \\
& $(0.0908)$ \\
\hline R-squared & $0.6764^{* * *}$ \\
\hline Adjusted R-squared & $10.0908)$ \\
\hline Standard error of regression & 0.8793 \\
\hline F-statistic & 0.8712 \\
\hline Durbin-Watson statistic & $1,142.260$ \\
\hline Breusch-Godfrey serial correlation LM test stat. & $109.2521^{* * *}$ \\
\hline Jarque-Bera test statistic & 1.5007 \\
\hline Breusch-Pagan-Godfrey heterosked. test stat. & 2.1837 \\
\hline
\end{tabular}

Note: statistically significant at significance level of: ${ }^{*} 10 \%,{ }^{* *} 5 \%,{ }^{* * *} 1 \%$.

Source: authors.

Despite the full multiple linear regression model, where variable INTBOOK is dependent and variables GDPpc_PPS, EDUC_L5-L8 and DIGSKILLS are independent, turned to be in general highly statistically significant ( $F=70.99$, $p$-value $<0.0001$ ), it has been shown that variable EDUC_L5-L8 is not statistically significant $(t=0.4597, p-$ value $=0.6492$ ). Because of that in the Table 5 the main results of the multiple linear regression model, where dependent variable is INTBOOK and independent variables are GDPpc_PPS and DIGSKILLS, is only shown. The standardized coefficients have shown that variable DIGSKILLS again has the highest relative impact on variable INTBOOK. On that way it can be concluded that variable digital skills is the most important in describing of changes in variable Internet use for travel and accommodations services.

\section{K-means clustering of countries}

In the following analysis, all four observed variables will be used together to group observed countries according to values of those variables. On that way different 
groups of countries with unique characteristics will be observed. In order to group countries, k-means clustering algorithm will be used. Squared Euclidean distances will be used as a distance measure whereas the maximized initial distance between cluster centres is chosen as well. According to the rule of thumb the number of clusters should be equal to $\sqrt{n / 2}$ (Hair et al., 1987, Wooldridge, 2013). In the analysis data for 33 European countries is observed and because of that it has been decided that the clustering procedure should result in four clusters solution.

In order to validate successfulness of clustering, results from analysis of variance table are observed. The results have shown that all four included variables can be treated as highly statistically significant in the clustering process (all corresponding $\mathrm{p}$ values are smaller than 0.0001 ).

Table 6 Cluster members, k-means clustering, squared Euclidean distances, $g=4$ variables, $n=33$ countries

\begin{tabular}{|c|c|c|c|}
\hline Cluster 1 & Cluster 2 & Cluster 3 & Cluster 4 \\
\hline Belgium; Cyprus; & Bulgaria; Croatia; & Austria; Czech & Denmark; Finland; \\
Ireland & Greece; Hungary; & Republic; Estonia; & Iceland; \\
& Italy; Latvia; & France; Germany; & Netherlands; \\
& Lithuania; & Malta; Slovakia; & Norway; Sweden; \\
& Montenegro; Poland; & Slovenia; Spain & Switzerland; United \\
& Portugal; Romania; & & Kingdom \\
& The Former Yugoslav & & \\
& Republic of & & \\
& Macedonia; Turkey & & \\
& & & \\
\end{tabular}

Source: authors.

In Table 6 the cluster members of the clusters are shown. The Cluster 1 has only three countries whereas the Cluster 2 is the largest with 13 countries. The Cluster 3 is consisted of 9 countries and in the Cluster 4 can be found 8 countries. According to Table 6 all four observed WB countries (Croatia, Montenegro, the Former Yugoslav Republic of Macedonia and Turkey) can be in the same cluster (in the Cluster 2).

Table 7 Cluster means, k-means clustering, squared Euclidean distances, $g=4$ variables, $n=33$ countries

\begin{tabular}{|c|c|c|c|c|}
\hline \multirow{2}{*}{ Cluster } & \multicolumn{4}{|c|}{ Variable } \\
\cline { 2 - 5 } & INTBOOK & GDPPC_PPS & EDUC_L5-L8 & DIGSKILLS \\
\hline 1 & 42.33 & 128.33 & 37.70 & 53.00 \\
2 & 18.23 & 64.92 & 22.54 & 42.62 \\
3 & 43.44 & 96.78 & 27.08 & 59.56 \\
4 & 58.00 & 128.38 & 35.58 & 76.50 \\
\hline
\end{tabular}

Source: authors.

In Table 7 cluster means of the four observed variables for the countries in the clusters are provided. It has been shown that countries in the Cluster 2, among which can be found WB countries, have the lowest average values at all four observed variables. On the other hand, countries which can be found in the Cluster 4 have the highest values of averages at almost all four variables. Only countries from the Cluster 1 have slightly higher EDUC_L5-L8 average than the Cluster 4 countries. It is interesting to observe that countries from the Cluster 1 and the Cluster 4 have almost the same GDPPC_PPS and EDUC_L5-L8 averages, but countries from the Cluster 4 have higher DIGSKILLS average and therefore higher INTBOOK average as well. In order to better describe differences between the clusters, normalized cluster means 
are shown in Figure 2 whereas graphs of distributions for observed variables are given in Figure 3.

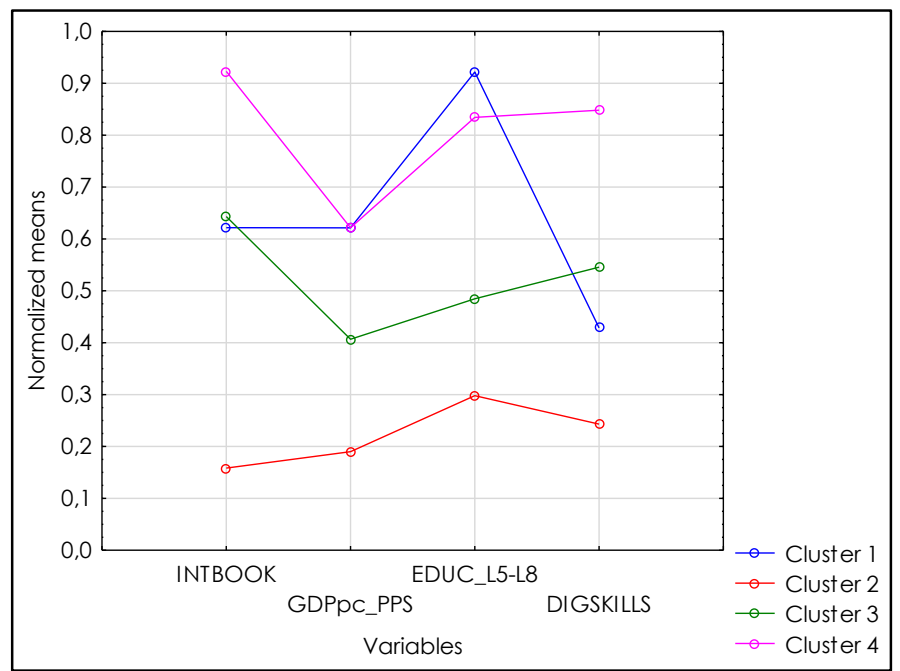

Figure 2 Normalized cluster means, k-means clustering, squared Euclidean distances, Source: authors. $\mathrm{g}=4$ variables, $\mathrm{n}=33$ countries

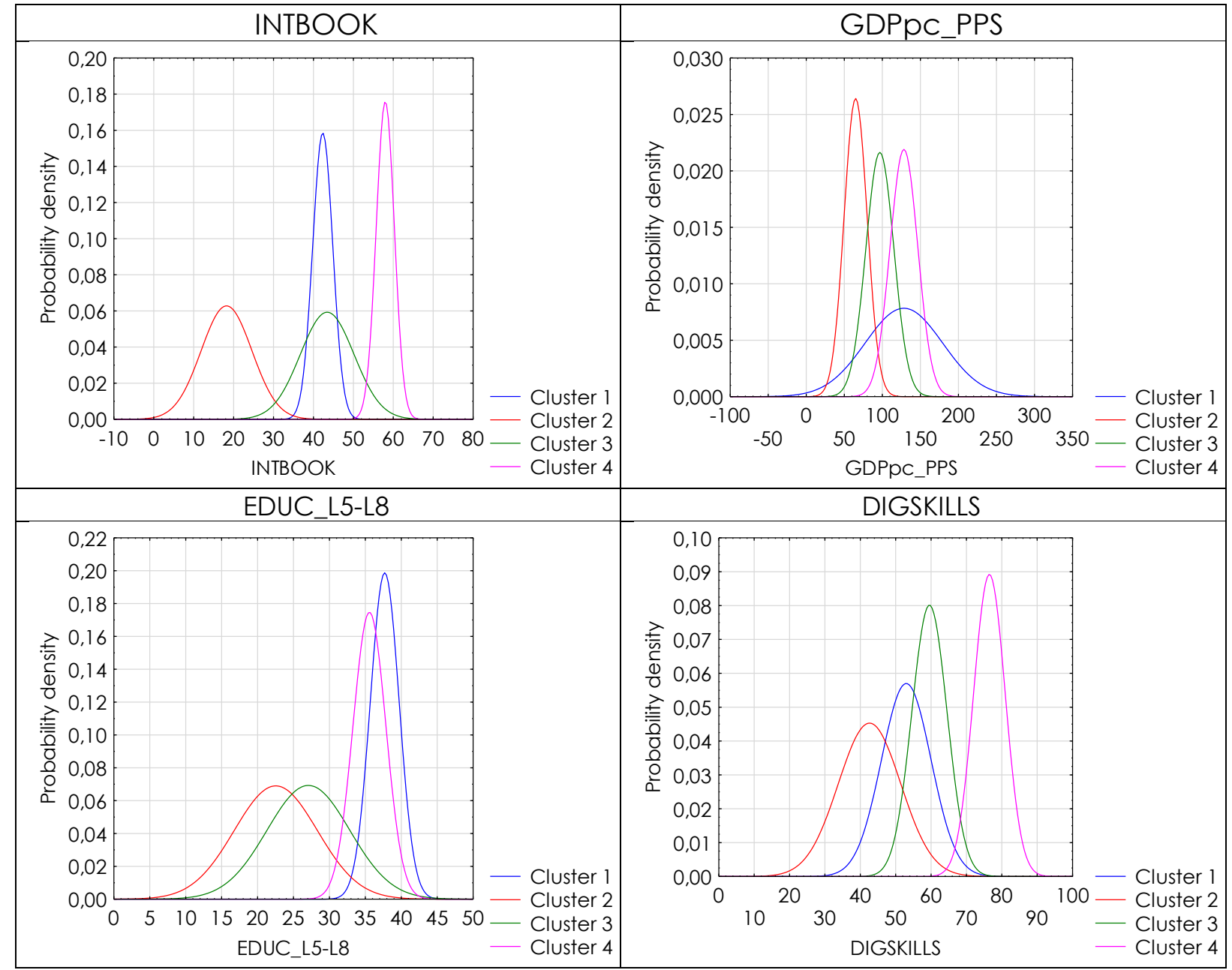

Figure 3 Graphs of distributions for observed variables, k-means clustering, squared Euclidean distances, $g=4$ variables, $n=33$ countries

Source: authors. 
The results from K-means clustering of countries show that the WB countries belong to a group of European countries with the lowest levels of the observed variables. Figures 2 and 3 clearly show that countries from the Cluster 2, where WB countries can be found, have convincingly the lowest values of variable INTBOOK. On that way it can be concluded that the WB countries have really undeveloped online booking for travel and accommodation level in compare to the other European countries.

\section{Conclusions}

The development of Internet has changed many things in everyday life of individuals. One of such thing is ability to use Internet for travel and accommodation services. By using Internet individuals can easily make their travel arrangement and book accommodation at a location of their choice. Nowadays the tourism got very important position in the development of each country. Consequently, the importance of the possibility to use Internet for travel and accommodation services increases as well.

The research has shown that digital skills have greater relative impact on use Internet for travel and accommodations services than the development variables like GDP per capita or share of highly educated individuals. That finding suggest that individuals should be more taught about how to use Internet and to develop their Internet and digitals skills.

Unfortunately, the research has shown that the WB countries are way back in compare to the other European Union when use Internet for travel and accommodations services is observed. Not only the WB countries lagging behind other European countries according to that, but they fall behind according to values of other development variables which are crucial for use Internet for travel and accommodations services development.

The main limitation of the paper can be found in the fact that not all WB countries are observed. On that way somewhat limited conclusions could be made. Because of that, it is recommended to, for the purpose of future research, try to collect data for all WB countries.

\section{References}

1. Dumičić, K., Žmuk, B., Čeh Časni, A. (2015). Impacts on travel and holiday accommodation online booking in selected South-East European countries: a multivariate analysis approach. Croatian Operational Research Review, Vol. 6, No. 1, pp. 155-168.

2. Dumičić, K., Žmuk, B., Čeh Časni, A. (2016). Factor Analysis of Determinants of Internet Booking Use by Europeans. World academy of science, engineering and technology conference proceedings international science index 18, London, United Kingdom, June 23-24, 2016, World academy of science, engineering and technology (WASET), ICMEFB 2016, London, pp. 2470-2478.

3. Dumičić, K., Žmuk, B., Mihajlović, I. (2016). Panel Analysis of Internet Booking of Travel and Holiday Accommodation Indicators. Interdisciplinary description of complex systems, Vol. 14, No. 1, pp. 23-38.

4. European Commission (2010). Communication from the Commission to the European Parliament, the Council, the European Economic and Social Committee and the Committee of the Regions: Europe, the World's No 1 Tourist Destination - a New Political Framework for Tourism in Europe. Available at https://eur-lex.europa.eu/legalcontent/EN/TXT/PDF/? uri=CELEX:52010DC0352\&from=EN [10 September 2018].

5. European Commission (2017). Special Eurobarometer 460 Attitudes towards the impact of digitisation and automation on daily life. Available at 
http://ec.europa.eu/commfrontoffice/publicopinion/index.cfm/Survey/getSurveyDetail/in struments/SPECIAL/surveyKy/2160 [06 October 2018].

6. European Commission (2018a). Digital Economy and Society Index (DESI): Methodological Note.

Available

http://ec.europa.eu/information_society/newsroom/image/document/2018-20/desi-2018methodology_E886EDCA-B32A-AEFB-07F591 1DE975477B_52297.pdf [23 November 2018].

7. European Commission (2018b). Overview of EU Tourism Policy. Available at https://ec.europa.eu/growth/sectors/tourism/policy-overview_en [23 November 2018].

8. Eurostat (2018a). GDP per capita in PPS, Index (EU28 = 100). Available at https://ec.europa.eu/eurostat/tgm/table.do?tab=table\&init=1 \&plugin=1 \&language=en \& pcode=tec00114 [06 November 2018].

9. Eurostat (2018b). Individuals - internet activities. Available at http://appsso.eurostat.ec.europa.eu/nui/show.do?dataset=isoc_ci_ac_i\&lang=en [06 November 2018].

10.Eurostat (2018c). Individuals who have basic or above basic overall digital skills by sex, \% of individuals aged 16-74. Available at https://ec.europa.eu/eurostat/tgm/table.do?tab=table\&init=1 \&plugin=1 \&language=en \& pcode=tepsr_sp410 [06 November 2018].

11.Eurostat (2018d). Population by educational attainment level, sex and age (\%) - main indicators.

Available

at

http://appsso.eurostat.ec.europa.eu/nui/show.do?dataset=edat_lfse_03\&lang=en [06 November 2018].

12.Hair, F. J., Anderson, E. R., Tahtam, L. R. (1987). Multivariate Data Analysis. Macmillan Publisching Company, New York.

13.Mihajlović, I. (2014a). The Impact of Global Trends at the Level of Macro Environment Dimensions on The Transformation of Travel Intermediaries: Case of The Republic of Croatia. WSEAS Transactions on Business and Economics, Vol. 11, No. 5707-082, pp. 663674.

14.Mihajlović, I. (2014b). ICT and New Trends in Consumer Behavior - New Experiential Knowledge, Opportunities or Challanges for Intermediaries. Journal of Marketing Management, Vol. 2, No. 1, pp. 43-64.

15.Mihajlović, I., Milić Beran, I., Krželj Čolović, Z. (2014). The Role of Technological Innovations as the Assumption of the Communication Efficiency between Service Providers and Tourists that Making Decisions about Travel. International Journal of Economics and Statistics, NAUN Athens, Vol. 2, pp. 257-269.

16.Mihajlovic, I., Raguz, L. (2018). Key drivers of business transformations in the environment of travel intermediaries. International journal of economics and statistics, Vol. 6, pp. 67-80.

17.Minghetti, V., Buhalis, D. (2010). Digital Divide in Tourism. Journal of Travel Research, Vol. 49, No. 3, pp. 267-281.

18.Mondekar, D. (2017). The Digital Economy in Southeast Europe: Opportunities and challenges. Friedrich-Ebert-Stiftung, Regional Office for Croatia and Slovenia, Zagreb.

19.The Institute of Economics, Zagreb (2018), SEE-6 Economic Outlook. Available at https://www.eizg.hr/userdocsimages/publikacije/serijske-publikacije/see6/see6_vol4_01.pdf [23 November 2018].

20.Wooldridge, J. M. (2013). Introductory Econometrics: A Modern Approach. South-Western College Publishing.

21.Žmuk, B. (2017). Speeding problem detection in business surveys: benefits of statistical outlier detection methods. Croatian Operational Research Review, Vol. 8, No. 1, pp. 33-59.

22.Žmuk, B., Dumičić, K., Mihajlović, I. (2014). On-line booking use for travel and holiday accommodation and development indicators: Clustering of European countries. Filipović, I., Klačmer Čalopa, M., Galetić, F. (Eds.), Proceedings of 7th International Scientific Conference Economic and Social Development, New York, October 24, 2014, pp. 508-518. 


\section{About the authors}

Berislav Žmuk graduated at the major Accounting, post-graduated Statistical Methods for Economic Analysis and Forecasting, and gained his PhD degree in Business Economics at Faculty of Economics and Business, University of Zagreb. Currently he is an Assistant Professor at Department of Statistics, Faculty of Economics and Business, University of Zagreb where he teaches following courses: Statistics, Business Statistics and Business Forecasting. In 2013, he successfully completed Sampling Program for Survey Statisticians (SPSS) at Survey Research Center (SRC), Institute for Social Research (ISR), and University of Michigan in Ann Arbor, Michigan, USA. In 2015 and in 2018, he completed several survey methodology courses (Introduction to Web Surveys, Introduction to Questionnaire Design, Mixed-Mode and MixedDevice Surveys, Applied Multiple Imputation, Web Survey Design, Sampling, Weighting, and Estimation) at Gesis, Leibniz Institute for Social Research in Cologne, Germany. In 2016, he completed another two survey methodology courses (Introduction to Survey Data Analysis, Advanced Survey Data Analysis and Survey Experiments) at Essex Summer School in Social Science Data Analysis in Colchester, United Kingdom. His main research fields include applications of statistics in business and economy, survey methodology and statistical quality control. The author can be contacted at bzmuk@efzg.hr.

Iris Mihajlović graduated at Faculty of Tourism and Foreign Trade, today's Department of Economics and Business Economics, University of Dubrovnik. She received her MSc Degree in Economics for Management at Faculty of Economics, University of Split, PhD degree in Economics, Trade and Tourism at Faculty of Economics and Business, University of Zagreb. Since 1998 she has been lecturing at Department of Economics and Business Economics in Dubrovnik, University of Dubrovnik, teaching courses up to graduate level in Marketing, Management and Tourism, holding currently the title of an Assistant Professor. She mentored more than 30 master students and participated at several scientific projects, granted by Croatian Science Foundation or by Ministry of Regional Development and EU Funds, as well as professional project granted by the City of Dubrovnik. Since 2014 she has been President of the Commission for Internal Quality Assurance and Enhancement System at Department of Economics and Business Economics. She participated as an invited lecturer at international conferences, reviewed number of articles for scientific conferences and published over 35 papers in scientific journals as well as two chapters in the books. Author can be contacted at iris.mihajlovic@unidu.hr. 